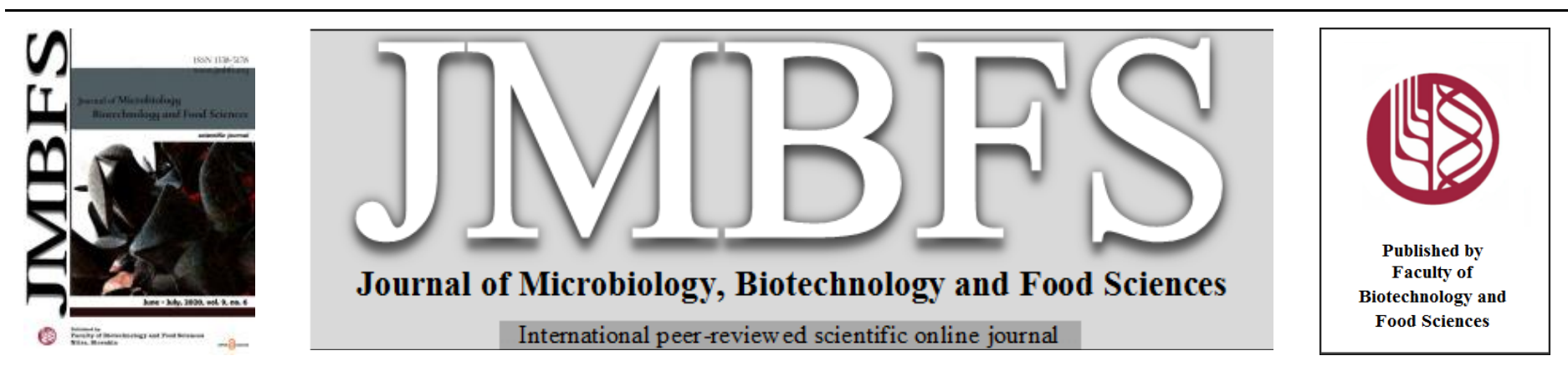

\title{
PREVALENCE, ANTIMICROBIAL RESISTANCE AND SUBSTANTIAL VIRULENCE-ASSOCIATED GENES OF ESCHERICHIA COLI ISOLATED FROM COLIBACILLOSIS IN NEONATAL CALVES IN EGYPT
}

\author{
Walid S. Mousa ${ }^{l}$ and Usama H. Abo Shama ${ }^{2 *}$ \\ Address(es): \\ ${ }^{1}$ Department of Animal Medicine and Infectious Diseases, Faculty of Veterinary Medicine, University of Sadat City, Egypt. \\ ${ }^{2}$ Department of Microbiology and Immunology, Faculty of Veterinary Medicine, Sohag University, Sohag 82524, Egypt.
}

*Corresponding author: Usama.shama@gmail.com

doi: 10.15414/jmbfs.2020.9.6.1145-1150

ARTICLE INFO

Received 13. 11. 2019

Revised 4. 2. 2020

Accepted 5. 2. 2020

Published 1. 6. 2020

Regular article

OPEN $\partial$ ACCESS

\begin{abstract}
Pathogenic Escherichia coli (E. coli) consider the most common bacterial agent causes calf diarrhea, particularly in newborn calves. Therefore, this study highlights prevalence, serotyping, antibiogram pattern of $E$. coli recovered from diarrheic calves in Egypt. In addition to the investigation of six virulence encoding genes (iss, fim $\mathrm{H}, t s h$, iutA, st $x 2$ and $e a e \mathrm{~A}$ ) using polymerase chain reaction (PCR). One hundred and twenty calves were examined for E. coli existence. A total of 16 (40\%) E. coli strains were isolated from 40 diarrheic calves samples. Seven E. coli serotypes (O26, O157, O78, O125, O146, O44, and O18) were recovered, and O26 and O157 were the most common. The tested strains exhibit high susceptibility to ciprofloxacin, enrofloxacin and polymixin and amoxicillin/clavulanic acid, while a high resistance to streptomycin, gentamycin, tetracycline, sulfamethoxazole/trimethoprim, chloramphenicol, and neomycin was recorded. The iss and $f i m \mathrm{H}$ genes were the most frequently identified virulence genes in all tested strains (100\%), followed by eaeA (31.25\%) and stx2 (6.25\%), whereas tsh and iutA were not detected at all. Our findings emphasize the existence of multi-antimicrobial resistance strain as well as virulence genes, which is crucial for developing novel methods to control of colibacillosis in calves.
\end{abstract}

Keywords: Escherichia coli, calf diarrhea, serotyping, antimicrobial profile, virulence genes

\section{INTRODUCTION}

Calf diarrhea represents a prevalent financial dilemma in the animal industry worldwide (Shahrani et al., 2014). Diarrhea is a common cause for high morbidity and case fatality rates, particularly in newborn calves. Various microorganisms, such as protozoa (Cryptosporidium parvum), viruses (coronavirus and rotavirus) and bacteria can cause diarrhea (Izzo et al., 2011) Although various bacterial types have been recovered from calves with diarrhea, E. coli remains an important noteworthy pathogenic bacterium in diarrheic calves and its prevalence varies according to geographic area (García et al., 2000).

In general, this bacterium lives naturally in both human and animal intestines. However, certain strains can become pathogenic by producing virulence factors and can, therefore, cause enteric infections (Picco et al., 2015). Many researchers recorded that among ruminant, cattle may implicate as the primary barrage for of enterovirulent $E$. coli that can transfer into humans through the food series (Pradel et al., 2001). Accordingly, E. coli is considered a leading cause of some clinical syndrome, such as septicemia, diarrhea, pneumonia, meningitis, and panophthalmitis especially in newborn calves and death in complicated dehydrated cases (Shahrani et al., 2014).

Based on their virulence factors, pathogenic E. coli strains can be divided into six types: (i) enteropathogenic $E$. coli (EPEC); (ii) enterotoxigenic $E$. coli (ETEC); (iii) enterohemorrhagic E. coli (EHEC), also known as shiga toxinproducing E. coli (STEC); (iv) enteroaggregative E. coli (EAEC); (v) diffusely adherent $E$. coli (DAEC); and (vi) enteroinvasive E. coli (EIEC) (Kaper et al., 2004). All these pathotypes are mainly associated with diarrheagenic strains. A number of probable virulence of $E$. coli strains are potential based on the presence of substantial factors, such as adheins, fimbriae, invasins, toxins, capsules, siderophores and hemolysins which play a critical role to avoid or suppress defenses and inflammatory response of the host (Bekal et al., 2003 and Croxen and Finlay, 2010)

Among the ETEC and EPEC pathotypes, molecular analysis has revealed a considerable divergence in virulence genotypes (Beutin et al., 2005). The pathogenicity of $E$. coli based mainly on adhesion and binding to the receptor of the mucosa of the small intestine using of fimbrial factors and exotoxins (Kaper et al., 2004) including F5 (K99), F41 and heat-stable enterotoxin (Acres, 1985).
Intimin (eae) gene and heat-stable enterotoxins were considered the most familiar virulence genotypes linked with EPEC E. coli (Mainil, 2013). Moreover, several virulence genes (stx 1 , st $x 2$, eae, ehly, hlyA, lt, st, cnf $1, c n f 2, c d t \mathrm{III}$ and $f 17 c$ ) are involved and predominated as virulence properties of $E$. coli strains particular of calves origin (Shahrani et al., 2014).

The use of antimicrobial agents is usually an effective tool applied for the prevention and treatment of neonatal calf diarrhea (Berge et al., 2009). However, this method may lead to the evolution of resistant bacterial strains to several antimicrobial drugs (Hammerum and Heuer, 2009). Furthermore, in recent years, much international surveillance recorded multidrug-resistant of $E$. coli strains of animals or human origin (Woodford et al., 2011). In animals, rapid evolution of antimicrobial resistance has been recently reported within E. coli isolates recovered from neonatal calves, especially those received growth promoters antibiotics in milk and milk substitutes (Pereira et al., 2011 and Tadesse et al., 2012).

The significant economic losses due to diarrhea in the dairy farm as well as in small-holder in Egypt encourage this work to investigate the prevalence, antimicrobial pattern, and distribution of the $i s s, f i m \mathrm{H}, t s h, i u t \mathrm{~A}, s t x 2$ and $e a e \mathrm{~A}$ virulence genes between, $E$. coli isolates recovered from diarrheic calves.

\section{MATERIALS AND METHODS}

\section{Sample collection and Study area}

The current study was performed from October 2018 to April 2019, through which cattle parturition rate is high. One-hundred and twenty calves under onemonth-old were monitored clinically for the incidence of diarrhea cases from small-holder in Menoufiya Province, Egypt. The clinical examination was done as described by Jackson and Cockcroft (2002), including clinical signs, systemic reaction, dehydration, pulse and respiratory rates. Forty fecal samples were aseptically collected from diarrheic calves using sterilized bacteriological swabs and directly transferred in the icebox to the lab for bacteriological examination.

Bacteriological examination of $E$. coli strains 
The collected fecal swab samples were inoculated into tryptose soy broth (mTSB- Difco La Jolla, CA, USA) and incubated at $37^{\circ} \mathrm{C}$ for 12 hours and then sub-cultured on a selective culture medium (MacConkey agar, MAC; Difco) at $37^{\circ} \mathrm{C}$ for one day. Pink color colonies were then picked up and cultured in eosin methylene blue (EMB; Difco) medium. Metallic green colonies were considered $E$. coli. Confirmation of all isolates were done through morphological characters, Gram staining and standard biochemical tests, including indole, citrate utilization, Voges-Proskauer, methyl red, Triple Sugar Iron (TSI), and urease tests as described by (Cowan and Steels, 1985) and biofilm activity on congo red medium according to (Nivedith et al., 2012).

\section{E. coli isolates Serotyping}

Serotyping using the slide agglutination test for $E$. coli isolates was done as described by (Edwards and Ewing, 1972).

\section{Antibiogram profile}

The antimicrobial susceptibility test of $E$. coli strains was performed using a Kirby-Bauer disk diffusion assay according to (CLSI, 2002). Bacteria suspension was prepared according to (Tenover, 2009). E. coli isolates were then examined in vitro for their susceptibility to 10 antimicrobial discs (Oxoid) tetracycline: TET, $(30 \mu)$; chloramphenicol C $(30 \mu)$; amoxicillin/clavulanic acid AMC $(30 \mu) ; \quad$ streptomycin $\mathrm{S}(10 \mu) ; \quad$ enrofloxacin $\operatorname{ENR}(5 \mu)$; sulfamethoxazole/trimethoprim SXT $(25 \mu)$; gentamicin CN $(10 \mu)$; neomycin N
$(30 \mu)$; ciprofloxacin CIP $(5 \mu)$; and polymixin PB (300IU). The inhibition zone was measured to survey the resistance or the susceptibility according to the interpretation criteria established by CLSI standard.

\section{Molecular characterization of $E$. coli serovars virulence genes}

Freshly grown typical E. coli-like colonies were collected and the DNA extraction was done according to the manufacturer's guidelines using QIAamp DNA Mini Kit DNA extraction kit (Qiagen, GmbH, Germany). All E. coli strains were screened for six virulence genes (iss, fim $\mathrm{H}, t s h, i u t \mathrm{~A}, s t x 2$ and $e a e \mathrm{~A}$ ) by PCR. Several PCR protocols were used to detect the target genes of E. col isolates. Lists of primers used, the PCR conditions, and the amplified products are listed in Tables 1. Amplification of DNA was carried out a total reaction of $25 \mu \mathrm{l}$ including $12.5 \mu \mathrm{l}$ of PCR Master Mix, $1 \mu \mathrm{l}$ of each primer of $20 \mathrm{pmol}$ concentration, $6 \mu \mathrm{l}$ of DNA template and $4.5 \mu \mathrm{l}$ of purified water. The primers (Metabion, Steinkirchen, Germany) used for detecting the virulence genes of $E$. coli (fim H and $t$ sh) (Colom et al., 2003), eaeA (Archambault et al., 2006), iss and iutA (Ghanbarpour and Salehi, 2010) and for st 2 gene (Bisi-Johnson et al., 2011).

The reactions were performed in an Applied Biosystems 2720 thermal cycler (Applied Biosystems, Foster, CA). Five microliter aliquots of all PCR products and a $100 \mathrm{bp}$ DNA ladder were loaded in the wells, electrophoresed through $1.5 \%$ agarose gels, stained with ethidium bromide and photographed under UV transillumite.

Table 1 Target genes, primer sequences, amplicon sizes and cycling conditions of virulence genes of $E$. coli isolates

\begin{tabular}{|c|c|c|c|c|c|c|c|}
\hline $\begin{array}{l}\text { Target } \\
\text { gene }\end{array}$ & $\begin{array}{l}\text { Primer sequences } \\
\text { Virulence genes }\end{array}$ & $\begin{array}{l}\text { Amplified } \\
\text { amplicon } \\
\text { (bp) }\end{array}$ & $\begin{array}{l}\text { Primary } \\
\text { denaturation }\end{array}$ & $\begin{array}{l}\text { Secondary } \\
\text { denaturation }\end{array}$ & Annealing & Extension & $\begin{array}{c}\text { Final } \\
\text { extension }\end{array}$ \\
\hline Iss & $\begin{array}{l}\text { ATGTTATTTTCTGCCGCTCTG } \\
\text { CTATTGTGAGCAATATACCC }\end{array}$ & 266 & $\begin{array}{l}94^{\circ} \mathrm{C} \\
5 \mathrm{~min} .\end{array}$ & $\begin{array}{l}94^{\circ} \mathrm{C} \\
30 \mathrm{sec} .\end{array}$ & $\begin{array}{l}54^{\circ} \mathrm{C} \\
30 \mathrm{sec} .\end{array}$ & $\begin{array}{l}72^{\circ} \mathrm{C} \\
30 \mathrm{sec} .\end{array}$ & $\begin{array}{l}72^{\circ} \mathrm{C} \\
7 \mathrm{~min} .\end{array}$ \\
\hline $\operatorname{fim} \mathrm{H}$ & $\begin{array}{l}\text { TGCAGAACGGATAAGCCGTGG } \\
\text { GCAGTCACCTGCCCTCCGGTA }\end{array}$ & 508 & $\begin{array}{l}94^{\circ} \mathrm{C} \\
5 \mathrm{~min} .\end{array}$ & $\begin{array}{l}94^{\circ} \mathrm{C} \\
30 \mathrm{sec} .\end{array}$ & $\begin{array}{l}50^{\circ} \mathrm{C} \\
45 \mathrm{sec} .\end{array}$ & $\begin{array}{l}72^{\circ} \mathrm{C} \\
45 \mathrm{sec} .\end{array}$ & $\begin{array}{l}72^{\circ} \mathrm{C} \\
10 \mathrm{~min} .\end{array}$ \\
\hline Tsh & $\begin{array}{l}\text { GGT GGT GCA CTG GAG TGG } \\
\text { AGT CCA GCG TGA TAG TGG }\end{array}$ & 620 & $\begin{array}{l}94^{\circ} \mathrm{C} \\
5 \mathrm{~min} .\end{array}$ & $\begin{array}{l}94^{\circ} \mathrm{C} \\
30 \mathrm{sec} .\end{array}$ & $\begin{array}{l}54^{\circ} \mathrm{C} \\
30 \mathrm{sec} .\end{array}$ & $\begin{array}{l}72^{\circ} \mathrm{C} \\
30 \mathrm{sec} .\end{array}$ & $\begin{array}{l}72^{\circ} \mathrm{C} \\
10 \mathrm{~min} .\end{array}$ \\
\hline iut $\mathrm{A}$ & $\begin{array}{l}\text { GGCTGGACATGGGAACTGG } \\
\text { CGTCGGGAACGGGTAGAATCG }\end{array}$ & 300 & $\begin{array}{l}94^{\circ} \mathrm{C} \\
5 \mathrm{~min} .\end{array}$ & $\begin{array}{l}94^{\circ} \mathrm{C} \\
30 \mathrm{sec} .\end{array}$ & $\begin{array}{l}63^{\circ} \mathrm{C} \\
45 \mathrm{sec} .\end{array}$ & $\begin{array}{l}72^{\circ} \mathrm{C} \\
30 \mathrm{sec} .\end{array}$ & $\begin{array}{l}72^{\circ} \mathrm{C} \\
7 \mathrm{~min} .\end{array}$ \\
\hline eaeA & $\begin{array}{l}\text { ATG CTT AGT GCT GGT TTA GG } \\
\text { GCC TTC ATC ATT TCG CTT TC }\end{array}$ & 248 & $\begin{array}{l}94^{\circ} \mathrm{C} \\
5 \mathrm{~min} .\end{array}$ & $\begin{array}{l}94^{\circ} \mathrm{C} \\
30 \mathrm{sec} .\end{array}$ & $\begin{array}{l}51^{\circ} \mathrm{C} \\
30 \mathrm{sec} .\end{array}$ & $\begin{array}{l}72^{\circ} \mathrm{C} \\
30 \mathrm{sec} .\end{array}$ & $\begin{array}{l}72^{\circ} \mathrm{C} \\
7 \mathrm{~min} .\end{array}$ \\
\hline
\end{tabular}

All genes were amplified for 35 cycles.

\section{RESULTS AND DISCUSSION}

\section{Prevalence and clinical examination of diarrheic calves}

Calf diarrhea is considered a major acute disease in neonatal calves causing high mortality and significant economic losses. This syndrome caused by multiple etiology (e.g. bacteria, viruses, protozoa) led to severe mucoid diarrhea, dehydration and rapid weight loss and may end with death in complicated nontreated calves (Galal et al., 2013 and Cho and Yoon, 2014). E. coli is the primary bacterial etiological agent responsible for calf diarrhea (Osman et al. 2012).

In our present work, a total of 120 samples were collected from under one month old calves that monitored clinically for the incidence of diarrhea cases from small-holder in Menoufiya Province, Egypt and examined for the incidence of $E$. coli. The clinical observation and examination of diseased calves revealed profuse watery and mucoid diarrhea with a variable degree of dehydration that was detected by a decrease in skin elasticity, sunken eyes, cold extremities and inability to stand. All affected calves were depressed and had a rapid pulse and respiratory rates and rough coats. Systemic reactions were observed in some of the affected animals.

Of 120 examined calves samples, forty $(33.3 \%)$ were diarrheic, sixteen $(40 \%)$ of the examined diarrheic calves were positive for E. coli. Our result, nearly similar to those of other studies in India reported by (Malik et al., 2013 and Shekhar et al., 2017) who isolated $E$. coli from diarrheic calves samples with a prevalence rate of $37.61 \%$ and $41.6 \%$, respectively. In Egypt (Galal et al., 2013) reported an E. coli prevalence rate of $28.57 \%$. On contrary, this result was lower than that reported by (Osman et al., 2013; Anwarullah et al., 2014 and Majueeb et al., 2014) with a prevalence rate of $63.6 \%, 72.8 \%$, and $50 \%$, respectively. While, (Duse et al., 2015 and El-Seedy et al., 2016) reported a lower prevalence rate with $14.6 \%$ and $18.1 \%$, respectively. The variations in the results might attribute to the difference in the number of collected samples, geographical regions, stress factors, hygienic and management systems.

\section{Serogrouping of $E$. coli isolates}

Serogrouping of sixteen $E$. coli isolates in our study revealed that $\mathrm{O} 26$ and $\mathrm{O} 157$ were the most common identified $E$. coli serogroups with prevalence rate $25 \%$ of each type. Other E. coli serogroups (O78, O125, and O146) were identified with a prevalence rate of $12.5 \%$ for each and finally $E$. coli serogroups (O44 and O18) with a prevalence rate of $6.25 \%$ for each. Our results are in agreement with (Shahrani et al., 2014) who conducted that E. coli O26 and O157 were the most E. coli serogroups isolated from diarrheic calves. Other studies reported by (ElSeedy et al., 2016) revealed that $\mathrm{O} 26$ and $\mathrm{O} 103$ were the most prevalent $(17.7 \%$ of each) E. coli serogroups isolated from neonatal diarrheic calves. However, 
(Badouei et al., 2010) recorded that $\mathrm{O} 26$ is the most prevalent E. coli serotypes with $(18.4 \%)$ as well as $\mathrm{O} 157: \mathrm{H} 7, \mathrm{O} 111$, and $\mathrm{O} 26$ were also serotyped from diarrheic and non-diarrheic calves. While, (Saridakis et al., 1997) reported that O26, O114 and O119 were the most identified E. coli strains obtained from diarrheic calves. In addition to (Mora et al., 2011) who typing 52\% of bovine E. coli strains serovars as belonged to $\mathrm{O} 4, \mathrm{O} 20, \mathrm{O} 22, \mathrm{O} 26, \mathrm{O} 77, \mathrm{O} 105, \mathrm{O} 113$ $\mathrm{O} 157$, and $\mathrm{O} 171$ serovars. The variation in the dominate serogroups of $E$. coli may explain the difference in geographic areas and numbers of the collected samples.

\section{Antimicrobial susceptibility pattern of $E$. coli serotypes from diarrheic calves}

Concerning antimicrobial susceptibility testing in this study, tested $E$. coli strains showed sensitivity against ciprofloxacin, enrofloxacin, polymixin and amoxicillin/clavulanic acid with percentage $81.25 \%, 75 \%, 75 \%$ and $62.5 \%$, respectively. Meanwhile, streptomycin showed complete resistance $(100 \%)$; followed by gentamycin, tetracycline, sulfamethoxazole/trimethoprim and chloramphenicol $(81.25 \%$ for each) and neomycin- $(56.25 \%)$ were noticed (Table 2). Similar findings were reported by (Khachatryan et al., 2006) who showed that $E$. coli exhibit phenotypic resistance to streptomycin, sulfonamide and tetracycline. Other studies have supported our result recorded by (Pereira et al. 2011 and Shahrani et al., 2014) they showed that all isolates of E. col exhibited high susceptibility to ciprofloxacin and cefepime and resistance to tetracycline, streptomycin, and sulfamethoxazole-trimethoprim. However (Srivani et al., 2017) reported high antimicrobial resistance of STEC strains isolated from diarrheic calves to tetracycline $(63.21 \%)$ and susceptible to chloramphenicol, gentamycin $(96.33 \%)$ and imipenem $(99.06 \%)$ in addition to $69.81 \%$ of these strains expresses multidrug resistance. Furthermore, (Hang et al., 2019) found that tetracycline was detected as the most resistant antibiotic by $E$. coli strains followed by sulfamethoxazole, ampicillin, trimethoprim, and ciprofloxacin.

Table 2 Antibiogram of different $E$. coli isolates

\begin{tabular}{|c|c|c|c|c|c|c|c|}
\hline \multirow{2}{*}{ Antimicrobial class } & \multirow{2}{*}{ Antimicrobial agents } & \multicolumn{6}{|c|}{ No of $E$. coli isolates (\%) } \\
\hline & & $\mathbf{R}$ & $\%$ & $\mathrm{I}$ & $\%$ & $\mathrm{~S}$ & $\%$ \\
\hline Chloramphenicol & Chloramphenicol (C) & 13 & 81.25 & 2 & 12.5 & 1 & 6.25 \\
\hline Aminoglycosides & Streptomycin (S) & 16 & 100 & 0 & - & 0 & - \\
\hline Aminoglycosides & Gentamycin $(\mathrm{CN})$ & 13 & 81.25 & 3 & 18.75 & 0 & - \\
\hline Aminoglycosides & Neomycin $(\mathrm{N})$ & 9 & 56.25 & 4 & 25 & 3 & 18.75 \\
\hline Tetracycline & Tetracycline (TET) & 13 & 81.25 & 1 & 6.25 & 2 & 12.5 \\
\hline Beta-lactams & Amoxicillin/Clavulanic acid (AMC) & 4 & 25 & 2 & 12.5 & 10 & 62.5 \\
\hline Sulfonamides & Sulfamethoxazole/trimethoprim (SXT) & 13 & 81.25 & 1 & 6.25 & 2 & 12.5 \\
\hline Fluoroquinolones & Ciprofloxacin (CIP) & 0 & - & 3 & 18.75 & 13 & 81.25 \\
\hline Fluoroquinolones & Enrofloxacin (ENR) & 1 & 6.25 & 3 & 18.75 & 12 & 75 \\
\hline Polymixins & Polymixin B (PB) & 2 & 12.5 & 2 & 12.5 & 12 & 75 \\
\hline
\end{tabular}

$\mathbf{R}=$ Resistance $\quad \mathbf{I}=$ Intermediate $\quad \mathbf{S}=$ Sensitive

A comparative study in Egypt was carried out (El-Seedy et al., 2016) demonstrated that $E$. coli isolates had high susceptibility to marbofloxacin, spectinomycin, and neomycin. Otherwise, (Ortman and Svensson, 2004) discussed that trimethoprim/sulfa and enrofloxacin were considered an effective treatment for diarrhea in young calves.

The high resistances of $\mathrm{E}$. coli isolates to tetracycline in our study were previously supported by many authors (Schroeder et al., 2002; Rigobelo et al., 2006; Alberto et al., 2011 and Hang et al., 2019). However, higher resistance to streptomycin, gentamycin, tetracycline, chloramphenicol, sulfamethoxazole/trimethoprim and neomycin in our study was in contrary to other reports by (Wani et al., 2013; Rehman et al., 2014 and Srivani et al., 2017), that reported STEC isolates from diarrheic calves showed high susceptibility to gentamycin and chloramphenicol.

The high incidence of resistant or multi-resistant $E$. coli isolates in the present work may be attributed to that the wide and haphazard using of antimicrobials in animals for treatment, prevention, and control of infectious diseases, and as growth promoters for potential livestock production (Marshall and Levy, 2011) In Egypt, the random using of these traditional antibiotics without veterinarian prescription and the overuse or misuse of antimicrobials in the veterinary field by dairy farmers, lead to emerging of their resistance genes which are of public concern as it could be passed on to humans (WHO, 2014).

\section{Molecular detection of $E$. coli virulence genes}

Regarding E. coli strains, their pathogenicity mainly relies on the existence of powerful toxins and certain virulence determinants, of these shiga toxins (ST) and intimin (eaeA) that facilitate the adhesion and colonization of E. coli strains in the host cells (Oswald et al., 2000). Intimin (eaeA gene) is an essential genetic element for attaching/effacing (A/E) lesion formation. Moreover, numerous fimbriae genes are proposed to have critical roles in the adhesion, attachment, and colonization of E. coli (Mainil, 2013). Shiga toxins are responsible for binding to the glycolipids on (Gb3) sites on the cell surface, resulting in the stoppage of protein synthesis and causing cell death (Kaper et al., 2004).

In our study, the screening of six virulence genes in E. coli isolates (iss, fim $\mathrm{H}$, $e a e \mathrm{~A}$, st $x 2$, tsh and iut $\mathrm{A}$ ) was carried out using specific primers sets in PCR assay. The results revealed that iss and fim $\mathrm{H}$ were the most frequently detected genes in all tested isolates (Fig. 1A-B), followed by the intimin (eaeA) gene in $31.25 \%$ (Fig. 1C). Our results related to the study reported by (Kwon et al., 2008) who explaining the vital role of fimbrial genes such as F5 (K99) in E. coli colonization in the mucosa of the small intestine of calves and by studying the frequency of the iss gene he reported that iss gene ranged from 80 to $100 \%$. Other fimbrial genes (F41 and F17) were identified in ETEC in neonatal calves (Mellata et al., 2003). Another study reported by (Lynne et al., 2007) clarified the function of the iss and bor genes in the pathogenicity of E. coli strains and reported that these genes believed to prevent the effect of inhibitory mediators generated by the host complement and resist the process of phagocytosis, and therefore, enhance the pathogenic influence of $E$. coli strains on the target host. Likewise, the incidence of the $s t x 2$ gene in our investigation was low as existed in only one isolate (6.25\%) (Fig. 1D). Our results are in agreement with (Wilson et al., 1992), who revealed a lower incidence of the stx 2 gene $(3.5 \%)$ in E. coli strains of young calves in Canada. On contrary, in Egypt (Abotalp et al., 2017) recorded a high prevalence $(43.75 \%)$ of the st $x 2$ gene. Interestingly, neither the $t s h$ nor the iutA gene was detected in any tested samples in the current investigation, which attributed to variation in the results obtained by the researchers. In accordance with the previous study, (Saidenberg et al., 2013) illustrated that the frequency of the tsh gene in E. coli avian strains was $85.3 \%$. Another investigation in Egypt by (Abdulgayeid et al., 2015) revealed that the prevalence of the $t s h$ gene in $E$. coli of diarrheic calves was $100 \%$. This difference requires further investigation regarding the role and prevalence of this gene in animal species and the possibility of interspecies transmission and the environmental risk factor.

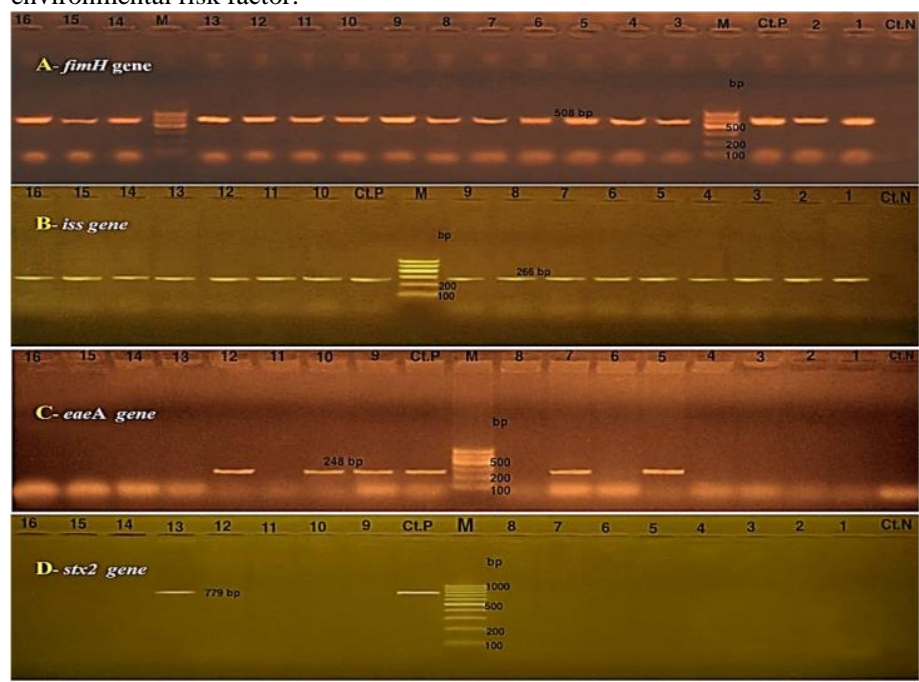

Figure 1 Agarose gel electrophoresis for PCR products for the detection of virulence genes in 16 E. coli strains; (A) All E. coli strains (1-16) were positive for the fim $\mathrm{H}$ gene $(508 \mathrm{bp})$. (B) All E. coli strains (1-16) were positive for the iss gene (266 bp). (C) Lanes 5, 7, 9, 10 and 12 were positive for the eaeA gene (248 
bp), while lanes $1,2,3,4,6,8,11,13,14,15$ and 16 were negative. (D) Only one strain (Lane 13) was positive for the stx2 gene (779 bp), whereas 15 strains (lanes 1-12 and 14-16) were negative for this gene. Lane M: 100 bp DNA marker; lane Ct.N: Negative control; and lane Ct.P: Positive control.

\section{Relationship between phenotypic resistance and virulence determinant genes among $E$. coli serotype}

The results in Table 3 showed a correlation between phenotypic resistance and virulence genes among different $E$. coli serotype, our finding emphasizes that the $E$. coli serotype which exhibits more phenotypic resistance carried more virulence genes. Moreover, E. coli $\mathrm{O} 26$ and $\mathrm{O} 157$ were the most E. coli serovars which exhibit multidrug resistance to more than five antimicrobial agents and carried three virulence determinant genes. Other serovars (O78, O146, O125, $\mathrm{O} 18$, and $\mathrm{O} 44$ ) observed in our result also displayed multidrug resistance to three or more antimicrobial agents. The proper association between drug resistance and virulence genes determinants is still poorly unclear to understand. However, several evidence pointed out a correlation between phenotypic-resistance and virulence determinant genes (Orden et al., 2000; Rasko et al., 2008; Badri et al., 2009 and Bonyadian et al., 2014) clarified that many of the E. coli strains showed multidrug resistance to several antimicrobial groups and thus enhanced more virulence to these strains, which may lead to complicate the treatment of some urinary tract and enteric infections in animals. Additionally, (Srivani et al. 2017) observed that $69.81 \%$ of shiga toxingenic E. coli serovars from diarrheic calves expressed multidrug resistance and serovars which carried hly $\mathrm{A}$ and eae $\mathrm{A}$ genes may possess a zoonotic threat and high prevalence of multidrug resistance. A similar finding in Brazil was conducted by (Rigobelo et al., 2006) who described that STEC isolates of diarrheic calves showed $100 \%$ multidrug resistance. Meanwhile, (Kumar et al., 2013) explained that the indiscriminate and widespread use of antimicrobial drugs act as the main reason of prevalent multi-drug resistance among bacteria and obstacle in the treatment of many bacterial diseases.

Table 3 Relationship between antimicrobial resistance and virulence factor genes among E. coli serotype

\begin{tabular}{|c|c|c|}
\hline Isolates no. & Serotype & Phenotypic resistance \\
\hline 1 & $\mathrm{O} 26$ & S, TET, SXT, C, N, AMC \\
\hline 2 & $\mathrm{O} 26$ & $\mathrm{~S}, \mathrm{TET}, \mathrm{SXT}, \mathrm{C}, \mathrm{N}, \mathrm{PB}$ \\
\hline 3 & $\mathrm{O} 26$ & $\mathrm{~S}, \mathrm{TET}, \mathrm{SXT}, \mathrm{C}, \mathrm{N}, \mathrm{AMC}$ \\
\hline 4 & $\mathrm{O} 26$ & $\mathrm{~S}, \mathrm{TET}, \mathrm{SXT}, \mathrm{C}, \mathrm{N}$ \\
\hline 5 & $\mathrm{O} 157$ & S , TET, SXT, C, N, ENR, CIP, AMC \\
\hline 6 & $\mathrm{O} 157$ & S , TET, SXT, C, N, AMC \\
\hline 7 & O157 & S , TET, SXT, C, N, PB, AMC \\
\hline 8 & $\mathrm{O} 157$ & $\mathrm{~S}, \mathrm{TET}, \mathrm{SXT}, \mathrm{C}, \mathrm{N}, \mathrm{PB}$ \\
\hline 9 & $\mathrm{O} 78$ & $\mathrm{~S}, \mathrm{TET}, \mathrm{SXT}, \mathrm{C}, \mathrm{N}$ \\
\hline 10 & $\mathrm{O} 78$ & $\mathrm{~S}, \mathrm{TET}, \mathrm{SXT}, \mathrm{C}$ \\
\hline 11 & $\mathrm{O} 125$ & $\mathrm{~S}, \mathrm{TET}, \mathrm{SXT}, \mathrm{C}$ \\
\hline 12 & $\mathrm{O} 125$ & S , TET, SXT, C, AMC \\
\hline 13 & O146 & $\mathrm{S}, \mathrm{TET}, \mathrm{SXT}, \mathrm{C}$ \\
\hline 14 & O146 & $\mathrm{S}, \mathrm{ENR}, \mathrm{PB}$ \\
\hline 15 & $\mathrm{O} 44$ & S, CIP, ENR \\
\hline 16 & $\mathrm{O} 18$ & S, CIP, ENR \\
\hline
\end{tabular}

Legend $\mathbf{S}=$ Streptomycine $\quad$ TET=Tetracycline $\quad$ SXT=Sulfamethozol/Trimethoprim $\mathbf{C}=$ Chloramphenicol

AMC=Amoxicillin/Clavulanic acid

ENR=Enrofloxacin $\quad$ CIP=Ciprofloxacin

CONCLUSSION

Given from the above-mentioned results, concluded the high importance of diarrhegenic $E$. coli which constitute a potential problem in neonatal calves as well as it acts as a source of infection dissemination in animal population. The problem is more dangerous with the existence of multi-antimicrobial resistant strains as well as $E$. coli associated virulence genes that could contribute to the capability of $E$. coli to cause diarrhea in calves. Furthermore, it is significant to provide valuable knowledge about the virulence ability of the circulating $E$. coli strains in Egypt and the ideal methods for prevention and control of such problems in the animal industry.

Ethics statement: This study was approved by the Ethics Committee and current legislation on research and ethical approval of the Faculty of Veterinary Medicine (Local ethical approval), Sohag and Sadat City Universities.

Conflict of Interest: The authors declare that they have no conflict of interest.

Funding: This research did not receive any specific grant from funding agencies in the public, commercial or not-for-profit sectors.

\section{REFERENCES}

Abdulgayeid, M., Shahin, H., Foad, S., Madiha, S. \& Ibrahim, S.M. (2015) Molecular Characterization of Escherichia Coli Isolated from Buffalo Calves in El-Behera Governorate. Alex J Vet Sci 47, 90-96. DOI: 10.5455/ajvs.202843

Abotalp, E.H., Eman-Abdeen, E., Alaa El-Din, H.M. \& Sahar, R.M. (2017) Molecular Detection of Virulence Genes of Escherichia coli O157 Isolated from Different Sources. Alex J Vet Sci 53, 38-44. DOI:10.5455/ajvs.262860

Acres, S.D. (1985). Enterotoxigenic Escherichia coli infections in newborn calves: a review. J. Dairy Sci 68, 229-256. DOI: 10.3168/jds.S00220302(85)80814-6

Alberto, M., Pilar, H., Sonia, J., de la Fuente, R., RuizSanta-Quiteria, J.A., Gustavo, D.B. \& Orden, J.A. (2011). Phenotypic and genotypic characterization of antimicrobial resistance in enterohemorrhagic Escherichia coli and atypical enteropathogenic E. coli strains from ruminants. J. Vet. Diagn. Invest 23, 91-95. https://doi.org/10.1177/104063871102300114

Anwarullah, M., Khan, J.A, Khan, M.S., Ashraf, K. \& Avais, M. (2014). Prevalence of Salmonella and Escherichia coli associated with diarrhea in buffalo and cow calves. Buffalo Bull 33, 332-336.

Archambault, M., Petrov, P., Hendriksen, R.S., Asseva, G., Bangtrakulnonth, A., Hasman, H. \& Aarestrup, F.M. (2006). Molecular characterization and occurrence of extended-spectrum beta-lactamase resistance genes among Salmonella enterica serovar Corvallis from Thailand, Bulgaria, and Denmark. Microb Drug Resist 12, 192-198. DOI: 10.1089/mdr.2006.12.192

Badri, S., Fassouane, A., Bouslikhane, M., Filliol, I., Hassar, M. \& Cohen, N. (2009). Relationship between susceptibility to antimicrobials and virulence factors in Escherichia coli isolated from food in Morocco. Internet J Food Saf 11, 98-101.

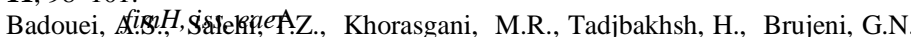
\&Nadalian, M.G. (2010). Virulence gene profiles and intimin subtypes of Shiga toxin-prodfiping isescherichia coli isolated from healthy and diarrhoeic calves Veterinary Reçord 167, 858-861.

Bekal, S., Brousseau, R., Masson, L., Prefontaine, G., Fairbrother, J. \& Harel, J. (2003).Rapid identification of Escherichia coli pathotypes by virulence gene detection with DNA microarrays. $J$ Clin Microbiol 41, 2113-2125. DOI 10.1128/jcm.41.5.2113-2125.2003

Berge, A.C., Moore, D. A., Besser, T.E. \& Sischo. W.M. (2009). Targeting therapy to minimize antimicrobial use in preweaned calves: Effects on health, growth, and treatment costs. J. Dairy Sci 92, 4707-4714. DOI: 10.3168/jds.20092199 fim $H$, iss

Beutin, L., Kaulfuss, S., Herold, S., Oswald, E. \& Schmidt, H. (2005). Genetic analysis offintrumpathogenic and enterohemorrhagic Escherichia coli sero-group O103 strains by molecular typing of virulence and housekeeping genes and pulsed-fielfimHgeliss electrophoresis. $J$ Clin Microbiol 43, 1552-1563. DOI:10.1128/JCM.43.4.1552-1563.2005

Bisi-Johnsfin, hyi\$., Obi, C.L., Vasaikar, S.D., Baba, K.A. \& Hattori, T. (2011) Molecular basis of virulence in clinical isolates of Escherichia coli and Salmonell fimpecies from a tertiary hospital in the Eastern Cape, South Africa. Gut Pathog 3,9-16, DOI: 10.1186/1757-4749-3-9.

Bonyadian, M., Moshtaghi, H., \& Taheri, M.A. (2014). Molecular characterization and antibiotic resistance of enterotoxigenic and enteroaggregative Escherichia coli isolated from raw milk and unpasteurized cheeses. Vet Res Forum 5, 29-34. PMCID: PMC4279659

Cho, Y.I. \& Yoon, K.J. (2014). An overview of calf diarrhea-infectious etiology, diagnosis, and intervention. J. Vet. Sci 15, 1-17. DOI:10.4142/jvs.2014.15.1.1

CLSI (2002). Performance standards for antimicrobial disk and dilution susceptibility tests for bacteria isolated from animals. Approved standard, $2^{\text {nd }}$ ed NCCLS document M31-A2. Clinical and Laboratory Standards Institute, Wayne, PA.

Colom, K., Pèrez, J., Alonso, R., Fernández-Aranguiz, A., Lariňo, E. \& Cisterna R. (2003). Simple and reliable multiplex PCR assay for detection of blaTEM blaSHV and blaOXA-1 genes in Enterobacteriaceae. FEMS Microbiol Lett 223, 147- 151. https://doi.org/10.1016/S0378-1097(03)00306-9

Cowan, S.T. Cowan \& Steels (1985). Manual for Identification of Medical Bacteria. $2^{\text {nd }}$ Edn., p. 138 -139, Cambridge University Press, London.

Croxen, M.A. \& Finlay, B.B. (2010). Molecular mechanisms of Escherichia coli pathogenicity. Nat Rev Microbiol 8:26-38. DOI:10.1038/nrmicro2265 
Duse, A., Waller, K.P., Emanuelson, U., Unnerstad, H.E., Persson, Y. \& Bengtsson, B. (2015). Risk factors for antimicrobial resistance in fecal Escherichia coli from preweaned dairy calves. J Dairy Sci 98, 500-156. DOI: $10.3168 /$ jds.2014-8432

Edwards, P.R. \& Ewing, W.H. (1972). Identification of Enterobacteriaceae. 3rd ed. Burgess Publ. Co., Minneapolis Minnesota.

El-Seedy, F.R., Abed, A.H., Yanni, H.A. \& Abd El-Rahman, S.A.A. (2016) Prevalence of Salmonella and E. coli in neonatal diarrheic calves. Beni-Suef University Journal of Basic and Applied Sciences 5(1), 45-51. https://doi.org/10.1016/j.bjbas.2015.11.010

Galal, H.M., Hakim, A.S. \& Sohad, M.D. (2013). Phenotypic and virulence genes screening of Escherichia coli strains isolated from different sources in delta Egypt. Life Sci. J 10, 352-361. http://www.lifesciencesite.com

García, A., Ruiz-Santa-Quiteria, J.A., Orden, J.A., Cid, D., Sanz, R., GomezBautista, M. \& De la Fuente, R. (2000). Rotavirus and concurrent infections with other enteropathogens in neonatal diarrheic dairy calves in Spain. Comp Immunol Microbiol Infect Dis 23, 175 -183. DOI: 10.1016/S0147-9571(99)00071-5

Ghanbarpour, R. \& Salehi, M. (2010). Determination of Adhesin Encoding Genes in Escherichia coli Isolates from Omphalitis of Chicks. Amer J Anim Vet Sci 5, 91-96.

Hammerum, A. M. \& Heuer, O. E. (2009). Human health hazards from antimicrobial-resistant Escherichia coli of animal origin. Clin. Infect. Dis 48 916-921. DOI: $10.1086 / 597292$

Hang, B.P.T., Wredle, E., Börjesson, S., Sjaunja, K.S., Dicksved, J. \& Duse, A (2019). High level of multidrug-resistant Escherichia coli in young dairy calves in southern Vietnam. Tropical Animal Health and Production 51, 1405-1411. DOI: 10.1007/s11250-019-01820-6

Izzo, M.M., Kirkland, P.D., Mohler, V.L., Perkins, N.R., Gunn, A.A. \& House, J.K. (2011). Prevalence of major enteric pathogens in Australian dairy calves with diarrhea. Aust Vet J 89, 167-173. DOI:10.1111/j.1751-0813.2011.00692.x Jackson, P.G.G. \& Cockcroft, P.D. (2002). Clinical Examination of Farm Animals. Chapter 8, Clinical Examination of the Gastrointestinal System. pp, 81 112

Kaper, J.B., Nataro, J.P. \& Mobley, H.L. (2004). Pathogenic Escherichia coli Nat Rev Microbiol 2,123-140. DOI: 10.1038/nrmicro818

Khachatryan, A.R., Besser, T.E., Hancock, D.D. \& Call, D.R. (2006). Use of a non medicated dietary supplement correlates with increased prevalence of streptomycin-sulfa-tetracycline-resistant Escherichia coli on a dairy farm. Appl. Environ. Microbiol 72, 4583-4588. DOI:10.1128/AEM.02584-05

Kumar, A., Verma, A.K., Malik, S., Gupta, M.K., Sharma, A. \& Rahal, A (2013). Occurrence of extended spectrum beta-lactamases producing alpha hemolytic Escherichia coli in neonatal diarrhea. Pak. J. Biol. Sci 10(3), 923-929. DOI: $10.3923 /$ pjbs.2014.109.113

Kwon, S.G., Cha, S.Y., Choi, E.J., Kim, B., Song, H.J. \& Jang, H.K. (2008) Epidemiological prevalence of avian pathogenic E. coli differentiated by multiplex PCR from commercial chickens and hatchery in Korea. Bacteriol Virol $J$ 38, 179-188. https://doi.org/10.4167/jbv.2008.38.4.179

Lynne, A.M., Skyberg, J.A., Logue, C.M., Doetkott, C., Foley, S.L. \& Nolan, L.K. (2007). Characterization of a series of transconjugant mutants of an avian pathogenic Escherichia coli isolate for resistance to serum complement. Avian Dis 251, 771-776. DOI:10.1128/AEM.02634-07

Mailk, S., Kumar A., Verma, A.K., Gupta, M.K., Sharma, S.D., Sharma, A.K. \& Rahal, A. (2013). Incidence and drug resistance pattern of collibacillosis in cattle and buffalo calves in western Utter Pradesh in India. Journal of Animal Health and Production 1, 15-19. https://www.scopus.com/sourceid/21100901155

Mainil, J. (2013). Escherichia coli virulence factors. Vet Immunol Immunopathol 152:2-12. DOI:10.1016/j.vetimm.2012.09.032

Majueeb, U., Rehman, M.R., Javeed, A.S. \& Mohd, A.B. (2014). Molecular epidemiology and antibiotic resistance pattern of Enteropathogenic Escherichia coli isolated from bovines and their handlers in Jammu, India. J Adv Vet Anim Res 1, 177-181. DOI: 10.5455/javar.2014.a30

Marshall, B.M. \& Levy, S.B. (2011). Food animals and antimicrobials: impacts on human health. Clin Microbiol Rev 24, 718-733. DOI: 10.1128/CMR.00002-11 Mellata, M., Dho-Moulin, M,, Dozois, C.M., Curtiss, R., Brown, P.K., Arne, P., Bree, A., Desautles, C. \& Fairbrother, J.M. (2003). Role of virulence factors in resistance of avian pathogenic Escherichia coli to serum and in pathogenicity. Infect Immun 71, 536 -540. DOI: 10.1128/IAI.71.1.536-540.2003

Mora, A., Herrrera, A., López, C., Dahbi, G., Mamani, R., Pita, J.M., Alonso, M.P., Llovo, J., Bernárdez, M.I., Blanco, J.E., Blanco, M. \& Blanco. J. (2011) Characteristics of the Shiga-toxin-producing enteroaggregative Escherichia coli O104:H4 German outbreak strain and of STEC strains isolated in Spain. Int Microbiol 14, 121-141. DOI: 10.2436/20.1501.01.142

Niveditha, S., Pramodhini, S., Umadevi, S., Kumar, S. \& Stephen, S. (2012). The isola on and the biofilm formation of uropathogens in the patients with catheter associated urinary tract infec ons (UTIs). J. Clin. Diagn. Res., 6: 1478-1482.

Orden, J.A., Ruiz-Santa-Quiteria, J.A., Garcia, S., Cid, D. \& Delafuente, R. (2000). In vitro susceptibility of Escherichia coli strains isolated from diarrhoeic dairy calves to 15 antimicrobial agents. J Vet Med B Infect Dis Vet Public Health 47, 329-33 DOI:10.1046/j.1439-0450.2000.00356.x
Ortman, K. \& Svensson, C. (2004). Use of antimicrobial drugs in Swedish dairy calves and replacement heifers. Vet Rec 154, 136-140 DOI:10.1136/vr.154.5.136

Osman, K.M., Mustafa, A.M., Aly, M.A.K. \& Abd El-Hamed, G.S. (2012) Serotypes, virulence genes, and intimin types of shiga toxin-producing Escherichia coli and enteropathogenic Escherichia coli isolated from mastitic milk relevant to human health in Egypt. Vector Borne Zoonotic Dis 12, 297-305. DOI:10.1089/vbz.2010.0257

Osman, K.M., Mustafa, A.M., Elhariri, M. \& Abd Elhamed, G.S. (2013). The Distribution of Escherichia coli Serovars, Virulence Genes, Gene Association and Combinations and Virulence Genes Encoding Serotypes in Pathogenic E. coli Recovered from Diarrhoeic Calves, Sheep and Goat. Transboundary and Emerging Diseases 60, 69-78. DOI:10.1111/j.1865-1682.2012.01319.x

Oswald, E., Schmidt, H., Morabito, S., Karch, H., Marches, O. \& Caprioli, A. (2000) Typing of intimin genes in human and animal enterohemorrhagic and enteropathogenic Escherichia coli: characterization of a new intimin variant. Infect Immun 68, 64- 71. DOI:10.1128/iai.68.1.64-71.2000

Pereira, R.V.V., Santos, T.M.A., Bicalho, M.L., Caixeta, L.S., Machado, V.S \& Bicalho, R.C. (2011). Antimicrobial resistance and prevalence of virulence factor genes in fecal Escherichia coli of Holstein calves fed milk with and without antimicrobials. J. Dairy Sci 94, 4556-4565. DOI:10.3168/jds.2011-4337 Picco, N.Y., Alustiza, F.E., Bellingeri, R.V., Grosso, M.C., Motta, C.E. Larriestra, A.J., Vissio, C., Tiranti, K.I., Terzolo, H.R., Moreira, A.R. \& Vivas, A.B. (2015). Molecular screening of pathogenic Escherichia coli strains isolated from dairy neonatal calves in Cordoba province, Argentina. Rev Argent Microbiol 47, 95 - 102. DOI: 10.1016/j.ram.2015.01.006

Pradel, N., Boukhors, K., Bertin, Y., Forestier, C., Martin, C. \& Livrelli, V. (2001). Heterogeneity of Shiga toxin-producing Escherichia coli strains isolated from hemolytic-uremic syndrome patients, cattle, and food samples in centra France. Appl. Environ. Microbiol 67, 2460-2468. DOI: 10.1128/AEM.67.6.24602468.2001

Rasko, D.A., Rosovitz, M.J., Myers, G.S., Mongodin, E.F., Fricke, W.F., Gajer, P. \& Crabtree, J., Sebaihia, M., Thomson, N.R., Chaudhuri, R., Henderson, I.R., Sperandio, V. \& Ravel, J. (2008). The pangenome structure of Escherichia coli: comparative genomic analysis of $E$. coli commensal and pathogenic isolates. J Bacteriol 190, 6881-93. DOI:10.1128/JB.00619-08

Rehman, M.U., Rashid, M., Sheikh, J.A., Wani, S.A. \& Farooq, S. (2014) Multi-drug resistance among shiga toxin producing Escherichia coli isolated from bovines and their handlers in Jammu region, India. Vet. World 6, 655-658 DOI: 10.14202/vetworld.2013.655-658

Rigobelo, E.C., Gamez, H.J., Marin, J.M., Macedo, C., Ambrosin, J.A. \& Ávila F.A. (2006). Virulence factors of Escherichia coli isolated from diarrheic calves Braz. J. Vet. Res. Anim. Sci 58, 305-310. http://dx.doi.org/10.1590/S0102 $\underline{09352006000300003}$

Saidenberg, A.A.B., Allegretti, L., Astolfi-Ferreira, C.C.S., Ferreira, A.J.P, Almeida, M.A. \& Raso, T.F. (2013). Some virulence genes of Escherichia col isolated from cloacal swabs of healthy Alagoas Curassows (Pauxi mitu) in Brazil. $\begin{array}{lllll}\text { Pesquisa } & \text { Vet } & \text { Brasileira } & 33 & \text { 523-527. }\end{array}$ http://www.pvb.com.br/portal/pesquisa/120?term=C.S

Saridakis, H.O., el Gared, S.A., Vidotto, M.C. \& Guth, B.E. (1997). Virulence properties of Escherichia coli strains belonging to enteropathogenic (EPEC) serogroups isolated from calves with diarrhea. Vet Microbiol 54, 145-153. DOI:10.1016/s0378-1135(96)01278-3

Shahrani, M., Dehkordi, F.S. \& Momta, H. (2014). Characterization of Escherichia coli virulence genes, pathotypes and antibiotic resistance properties in diarrheic calves in Iran. Biol Res 47, 28 - 40. DOI:10.1186/0717-6287-47-28 Shekhar, S., Ranjan, R., Singh, C.V. \& Kumar, P. (2017). Prevalence, Clinicohaemato-Biochemical Alterations in Colibacillosis in Neonatal Calves. Int.J.Curr.Microbiol.App.Sci 6,

DOI: https://doi.org/10.20546/ijcmas.2017.609.393

Schroeder, C.M., Cuiwei, Z., Chitrita, D.R., Jocelyn, T., Shaohua, Z., White D.G., Wagner, D.D., McDermott, P.F., Walker, R.D. \& Meng, J. (2002) Antimicrobial resistance of Escherichia coli 0157 isolated from humans, cattle, swine, and food. Appl. Environ. Microbiol 68, 576-581. DOI:10.1128/aem.68.2.576-581.2002

Srivani, M., Reddy, Y.N., Subramanyam, K.V., Reddy, M.R. \& Srinivasa, R.T. (2017). Prevalence and antimicrobial resistance pattern of Shiga toxigenic Escherichia coli in diarrheic buffalo calves. Veterinary World 10, 774-778. DOI: $10.14202 /$ vetworld.2017.774-778

Tadesse, D.A., Zhao, S., Tong, E., Ayers, S., Singh, A., Bartholomew, M. J. \& McDermott, P.F. (2012). Antimicrobial drug resistance in Escherichia coli from humans and food animals, United States, 1950-2002. Emerg Infect Dis 18,742749. DOI: $10.3201 /$ eid1805.111153

Tenover, F.C. (2009). Antibiotic Susceptibility Testing. Encyclopedia of Microbiology (Third Edition). 67-77.

Wani, S.A., Hussain, I., Beg, S.A., Rather, M.A., Kabli, Z.A., Mir, M.A. \& Nishikawa, Y. (2013). Diarrhoeagenic Escherichia coli and Salmonellae in calves and lambs in Kashmir: Absence, prevalence and antibiogram. Sci. Tech Rev 32, 1-17. DOI:10.20506/rst.32.2.2213

Wilson, J.B., McEwen, S.A., Clarke, R.C., Leslie, K.E., Wilson, R.A., Waltner- 
Toews, D. \& Gyles, C.L. (1992). Distribution and characteristics of verocytotoxigenic Escherichia coli isolated from Ontario dairy cattle. Epidemiol Infect 108, 423-439. DOI: 10.1017/s0950268800049931

Woodford, N., Turton, J.F. \& Livermore, D.M. (2011). Multiresistant Gramnegative bacteria: the role of high-risk clones in the dissemination of antibiotic resistance. FEMS Microbiol Rev 35(5), 736-55. DOI:10.1111/j.1574$\underline{6976.2011 .00268 . x}$

World Health Organization (2014). Antimicrobial Resistance. Fact Sheet 194

World Health Organization. Avenue Appia, Geneva, Switzerland. 